Revue Française de Civilisation Britannique

The May 2016 Devolved Elections in Scotland, Wales, Northern Ireland and London: Convergences and Divergences

\title{
"My Dad was a bus driver". The 2016 mayoral elections in London
}

"Mon père était chauffeur de bus ». Les Elections à la mairie de Londres de 2016

\section{Timothy Whitton}

\section{OpenEdition \\ Journals}

Electronic version

URL: http://journals.openedition.org/rfcb/1583

DOI: $10.4000 /$ rfcb. 1583

ISSN: 2429-4373

Publisher

CRECIB - Centre de recherche et d'études en civilisation britannique

\section{Electronic reference}

Timothy Whitton, " "My Dad was a bus driver". The 2016 mayoral elections in London », Revue

Française de Civilisation Britannique [Online], XXII-4 | 2017, Online since 20 November 2017, connection on 07 May 2019. URL : http://journals.openedition.org/rfcb/1583 ; DOI : 10.4000/rfcb.1583

This text was automatically generated on 7 May 2019.

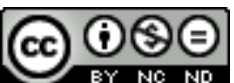

Revue française de civilisation britannique est mis à disposition selon les termes de la licence Creative Commons Attribution - Pas d'Utilisation Commerciale - Pas de Modification 4.0 International. 


\title{
"My Dad was a bus driver". The 2016 mayoral elections in London
}

«Mon père était chauffeur de bus ». Les Elections à la mairie de Londres de 2016

\author{
Timothy Whitton
}

\section{Introduction}

1 In May 2016 Sadiq Khan became the first "British" Muslim to be elected mayor of a European capital city, ushering in a new era of politics in London which will undoubtedly contrast starkly with the respective reigns of Ken Livingstone (2000 - 2008) and Boris Johnson (2008 - 2016). To his great pride, Livingstone had defied and to some extent beaten both Thatcher and Blair becoming the first directly elected mayor of London in May 2000 after running as an independent candidate. ${ }^{1}$ He renewed his victory in 2004 with the success of the Congestion Charge, this time round as New Labour's candidate, but lost in 2008 to Alexander Boris de Pfeffel Johnson and in 2012 when the incumbent piped him once again to the post.

The first four mayoral elections were by and large a battle of celebrity politics whereby the electorate would gauge a candidate's suitability for the job on his ability to be media friendly and jostle adroitly with the political establishment and his own party in order to show that his first loyalty, come what may, would be London and Londoners. Livingstone was familiar with municipal politics whereas Johnson surrounded himself with a team of advisors well equipped to rescue the mayor from his blunders which to a certain extent had become his trademark.

Both took on board the need for the mayor of London to avoid being a run-of-the-mill ordinary politician lurking permanently within the confines of City Hall: they very readily used the media to promote their personal style of politics and as celebrities in their own right found that signing autographs was another convenient way of linking up with the London electorate. Khan on the other hand, has made it clear that he will stay 
faithful to a more civic style of leadership, relying on team play rather than showmanship.

4 The aim of this article will be to briefly review the first four elections in London - mayor and assembly members - before comparing them with the 2016 elections when Khan, the "son of a bus driver" took over. ${ }^{2}$ His campaign will be examined in the light of what Londoners have come to expect of their mayor and of what he can actually deliver given the powers devolved to this decentralised authority.

\section{David against Goliath}

5 Had New Labour known the landslide victory they were going to achieve in the 1997 elections, it is quite possible that they would have been less afflicted with "manifestoitis" during the months afterwards. ${ }^{3}$ With a majority of 88 and having won 57 of the 74 seats in London, there was a priori little need to organise a referendum to ask Londoners if they thought that their city should be given a new central authority. Perhaps the 17 years spent on the benches of Her Majesty's opposition had left New Labour eager to carry out their electoral promises come what may in respect of what the "people" had chosen. ${ }^{4}$ The referendum was post legislative and returned a "yes" vote but only $34 \%$ of the London electorate took part. ${ }^{5}$ Notwithstanding this low turnout, New Labour pressed ahead with its plans to create a new central authority in London and the main political parties began searching more earnestly for their ideal candidate. The London mayor's mandate is particular given that the potential electorate of some five million people provides him with an important role to play in any party's national political strategy.

6 Having been excluded from being the party's candidate after New Labour's somewhat rigged primaries, Ken Livingstone, former leader of the Greater London Council, decided to run as an independent candidate. He was subsequently officially excluded from the Party for five years but undauntingly organised the "purple bus" campaign which entailed his team driving around London asking Londoners to "hoot for Ken". Sitting on the open roofed top deck, Livingstone made wild promises through a loudspeaker the sole aim of which was to show that he was the under trodden candidate who wanted to defend the capital city for Londoners rather than for any political party. ${ }^{6}$ His main crusade was the renovation of the underground which New Labour wanted to entrust to a Public Private Partnership whereas Livingstone was keen on financing it through a system of public bonds thus involving local people financially in the scheme.

7 His main opponents were Steven Norris for the Conservative Party and Frank Dobson who had emerged victorious from New Labour's primaries. The former had based his campaign on the need for London to be run by a manager rather than a politician and his manifesto Action not Politics reflected this approach. Dobson - rapidly nicknamed "Dobbo" by the press - tried somewhat desperately to convince Londoners that he was no party apparatchik and that he would have their interests at heart but the rigged primaries and a general disappointment with New Labour meant that his was going to be an uphill climb from the start. His final score was only some 20000 more than the Liberal Democrat's candidate, Susan Kramer. ${ }^{7}$

8 Livingstone's populist strategy paid dividends and despite his credibility being weakened during the May Day riots which meant his having to rely on second preference votes to win, he became the first directly elected mayor of London on May $4^{\text {th }} 2000 .{ }^{8}$ His first 
sentence on learning about his victory speaks volumes about the campaign that he had successfully organised, at times against all odds: "As I was saying before I was so rudely interrupted some fourteen years ago". Livingstone had indeed faced up to Thatcher in 1986 and fourteen years later taken on the party machine of New Labour.

2000 London mayor results

\begin{tabular}{|l|l|l|l|l|}
\hline Candidates & Political parties & First round result & Second round result & Total \\
\hline Ken Livingstone & Independent & $667,877(39 \%)$ & 108,550 & $\mathbf{7 7 6 , 4 2 7}$ \\
\hline Steve Norris & Conservative & $464,434(27 \%)$ & 99,703 & $\mathbf{5 6 4 , 1 3 7}$ \\
\hline Frank Dobson & New Labour & $223,884(13 \%)$ & eliminated & \\
\hline Susan Kramer & Lib-Dem & $203,452(11.9 \%)$ & eliminated & \\
\hline Ram Gidoomal & CPA & $42,060(2.5 \%)$ & eliminated & \\
\hline Darren Johnson & Green Party & $38,121(2.2 \%)$ & eliminated & \\
\hline Michael Newland & BNP & $33,569(2 \%)$ & eliminated & \\
\hline Damian Hockney & UKIP & $16,324(1 \%)$ & eliminated & \\
\hline Geoffrey Ben-Nathan & PA & $9,956(0.6 \%)$ & eliminated & \\
\hline Ashwinkumar Tanna & Independent & $9,015(0.5 \%)$ & eliminated & \\
\hline Dr Geoffrey Clements & NLP & $5,470(0.3 \%)$ & eliminated & \\
\hline
\end{tabular}

Registered electors: 5,093,464 ; Turnout: 1,714,162 (33.65\%)

CPA: Christian People's Alliance ; BNP: British National Party PA: Pro-automobile ; NLA: Natural Law Party

Sources: http://www.election.demon.co.uk/gla.html , http://www.mayorwatch.co.uk/indepth/gla-election-results , http://www.london.gov.uk/gla/elections/mayoral/

The competition to become the first mayor of London somewhat overshadowed the election on the same day of the 25 members of the London Assembly. Fourteen of them are elected on a constituency basis using the first-past-the-post system while the eleven London-wide Additional Members are chosen according to the d'Hondt method which is designed to give the smaller parties the chance to be represented. ${ }^{10}$ The assembly is essentially consultative but can block the mayor's budget if two thirds of its members disagree. The following table gives the assembly results of the elections since 2000:

Greater London Authority Assembly results 2000 - 2016

\begin{tabular}{|l|l|l|l|l|l|l|l|l|l|l|l|l|l|l|l|}
\hline \multicolumn{2}{|l|}{2000} & \multicolumn{2}{l|}{2004} & \multicolumn{2}{l|}{2008} & \multicolumn{2}{l|}{2012} & \multicolumn{2}{l|}{2016} \\
\hline & Cst & AM & Tot & Cst & AM & Tot & Cst & AM & Tot & Cst & AM & Tot & Cst & AM & Tot \\
\hline
\end{tabular}




\begin{tabular}{|l|l|l|l|l|l|l|l|l|l|l|l|l|l|l|l|}
\hline Lab & 6 & 3 & 9 & 5 & 2 & 7 & 6 & 2 & $\mathbf{8}$ & 8 & 4 & $\mathbf{1 2}$ & 9 & 3 & $\mathbf{1 2}$ \\
\hline C & 8 & 1 & $\mathbf{9}$ & 9 & 0 & $\mathbf{9}$ & 8 & 3 & $\mathbf{1 1}$ & 6 & 3 & $\mathbf{9}$ & 5 & 3 & $\mathbf{8}$ \\
\hline LD & 0 & 4 & 4 & 0 & 5 & 5 & 0 & 3 & 3 & 0 & 2 & 2 & 0 & 1 & $\mathbf{1}$ \\
\hline Gr & 0 & 3 & 3 & 0 & 2 & 2 & 0 & 2 & 2 & 0 & 2 & 2 & 0 & 2 & 2 \\
\hline UKIP & 0 & 0 & 0 & 0 & 2 & 2 & 0 & 0 & 0 & 0 & 0 & 0 & 0 & 2 & 2 \\
\hline BNP & 0 & 0 & 0 & 0 & 0 & 0 & 0 & 1 & $\mathbf{1}$ & 0 & 0 & 0 & 0 & 0 & 0 \\
\hline
\end{tabular}

Cst: constituency seats; AM: Additional member; Tot: total number of seats; C: Conservative ; D: Liberal Democrats Gr: Green Party ; BNP: British National Party

\section{The $2004 \& 2008$ elections}

The 2004 London election was a rematch between Livingstone and Steve Norris. The former had been reintegrated into the Labour Party which had lifted the five-year ban in the knowledge that the success of the Congestion Charge had given Livingstone a great deal of national and even international notoriety. ${ }^{11} \mathrm{He}$ now had a record which the electorate could assess to take their decision and New Labour knew that it would be better to win with the Congestion Charge champion rather than lose without him. ${ }^{12}$ Indeed, opinion polls were clearly showing that Livingstone had every chance of being elected for a second mandate in 2004 whichever party he chose to stand for. ${ }^{13}$

2004 London mayor results

\begin{tabular}{|l|l|l|l|l|}
\hline Candidates & Political parties & First round result & Second round result & Total \\
\hline Ken Livingstone & Labour & $685,541(36.8 \%)$ & 142,839 & $\mathbf{8 2 8 , 3 8 0}$ \\
\hline Steve Norris & Conservative & $542,423(29.1 \%)$ & 124,755 & $\mathbf{6 6 7 , 1 7 8}$ \\
\hline Simon Hughes & Lib-Dem & $284,645(15.3 \%)$ & eliminated & \\
\hline Frank Maloney & UKIP & $115,665(6.2 \%)$ & eliminated & \\
\hline Lindsey German & Respect & $61,731(3.3 \%)$ & eliminated & \\
\hline Julian Leppert & BNP & $58,405(3.1 \%)$ & eliminated & \\
\hline Darren Johnson & Green Party & $57,331(3 \%)$ & eliminated & \\
\hline Ram Gidoomal & CPA & $41,696(2.2 \%)$ & eliminated & \\
\hline Lorna Reid & IWCA & $9,542(0.5 \%)$ & eliminated & \\
\hline Tammy Nagalingam & Independent & $6,692(0.35 \%)$ & eliminated & \\
\hline
\end{tabular}



bomb attacks in London when in a very statesmanlike fashion he condemned the
atrocities that had killed 52 people and injured hundreds. ${ }^{14}$ For a short while, people
forgot his tendency to promote a rainbow plethora of minority causes in the capital city and it seemed as if nothing would stop him from romping to a third victory. Yet the "Kenocracy" that he was accused of constructing in London along with a series of highprofile political blunders was beginning to undermine his credibility or perhaps he felt that the lack of any real challenger gave him a free rein in City Hall. ${ }^{15}$ His opponents knew they needed to find a suitable candidate capable of defeating Livingstone on his own turf and plucked Alexander Boris de Pfeffel Johnson out of their top-hats. "Boris" had a safe parliamentary seat in Henley-on-Thames but realised quickly that mayor of London would be a high-profile job and perhaps a fast-track way of becoming party leader. He was also media friendly and a celebrity well known for hosting Have I Got News For You on various occasions. Above all, the campaign would be focussed on personalities rather than on programmes because there was little room for innovative projects in London given that the Olympic Games were looming ever larger. ${ }^{16}$

The key to Johnson's success was even so not just a question of celebrity politics. While in the last six months leading up to the elections in 2008 Livingstone had to deal with a multitude of affairs that tarnished his reputation, ${ }^{17}$ the Conservatives relied heavily on Lynton Crosby, the veteran Australian political strategist, whom they had drafted in to organise Johnson's campaign in London. Crosby encouraged the Conservative Party to concentrate their efforts on the outer Conservative-voting boroughs where votes could be won more easily by appealing to the electorate's traditional political leanings and exacerbating the feeling that they had been let down by the incumbent mayor, more inclined to look after inner or "zone 1 " London. ${ }^{18} \mathrm{He}$ insisted that the Conservatives should focus on the electorate just as much as on the opposition between "Ken" and "Boris". This approach was to pay dividends added to the allegations of corruption that weighed heavily against Livingstone enabling the popular press - and especially The Sun and the London paper the Evening Standard - to unleash all their venom on him, precipitating his downfall. When all is said and done, Johnson's slogan Time for a Change gave him the edge over Livingstone's somewhat stale attitude towards London, Londoners and the Greater London Authority.

2008 London mayor results

\begin{tabular}{|c|c|c|c|c|}
\hline Candidates & Political parties & $\begin{array}{ll}\text { First } & \text { round } \\
\text { result } & \end{array}$ & $\begin{array}{|ll|}\text { Second } & \text { round } \\
\text { result } & \end{array}$ & Total \\
\hline
\end{tabular}




\begin{tabular}{|c|c|c|c|c|}
\hline Boris Johnson & Conservative & $1,043,761(42.5 \%)$ & 124,977 & $1,168,738$ \\
\hline Ken Livingstone & Labour & 893,877 (36.4\%) & 135,089 & $1,028,966$ \\
\hline Brian Paddick & Lib-Dem & $236,685(9.6 \%)$ & eliminated & \\
\hline Siân Berry & Green Party & $77,374(3.1 \%)$ & eliminated & \\
\hline $\begin{array}{l}\text { Richard } \\
\text { Barnbrook }\end{array}$ & BNP & $69,710(2.8 \%)$ & eliminated & \\
\hline Alan Craig & CPA \& CP & 39,249 (1.6\%) & eliminated & \\
\hline Gerard Batten & UKIP & $22,422(0.9 \%)$ & eliminated & \\
\hline Lindsey German & Left List & $16,796(0.7 \%)$ & eliminated & \\
\hline Matt O'Connor & $\begin{array}{l}\text { English } \\
\text { Democrats }\end{array}$ & $10,695(0.4 \%)$ & eliminated & \\
\hline Winston McKenzie & Independent & $5,389(0.2 \%)$ & eliminated & \\
\hline
\end{tabular}

Registered electors: 5,419,193 Turnout: 2,456,990 (45.33\%)

CP: Christian Party ; See 2000 table for other abbreviations and sources.

Voter turnout for this election was particularly high given the duel that had been highly publicised in the national and even international medias between "Boris" and "Ken". Both candidates' scores were higher than in the preceding election but Johnson's was nearly double that of his predecessor, Steven Norris. Livingstone, on the other hand, was able to rely more on second preferences than his opponent but to a slightly lesser extent than in 2004. In this category, Johnson's score was similar to Norris'. To many intents and purposes, Crosby's strategy had worked and despite Livingstone's ability to harness second preference support from his political allies - such as the Green Party for example - first choices tipped the scales against him.

Concerning elections to the Assembly, for the first time the British National Party reached the 5\% threshold and won one Additional Member's seat. The Conservative party increased its overall proportion of votes - and thus AM seats - to the detriment of both Labour and the Lib-Dems with UKIP losing both their seats. With 11 assembly seats, Johnson was unlikely to face a challenge on his annual budget. For the first time, Respect and the Abolish the Congestion Charge "parties" appeared as political forces within London only to disappear four years later in the 2012 London elections.

\section{Turn again Boris and Ken}

The 2012 election was a repetition of 2008 especially when Livingstone won the competition to be the Labour Party's candidate against Oona King. It had been felt that she could be the better candidate to reach voters across the constituency boundaries in London given the 2010 general election results in the capital when Labour had lost six seats whereas the Conservatives had gained seven. Livingstone, on the other hand, had 
based his candidacy on an openly "anti-Tory anti-spending cut" platform demanding that the electorate should hold Johnson to account for his links with the Conservative Party. ${ }^{19}$ ${ }^{20}$ This harked back to the 1980s when the Greater London Council had openly opposed central government on a number of issues that more often than not had little to do with its remit. ${ }^{21}$ What tipped the balance in his favour - apart from the fact that he had said quite openly in March 2009 that he would run again as an independent should he fail to be chosen by Labour -, was most certainly the leadership contest in full swing within the Labour Party after the 2010 general election defeat. ${ }^{22}$ It was deemed preferable to rely on Livingstone's experience rather than King's ability to reach swing and suburban voters.

Inspired by the 2008 presidential elections in America, Livingstone relied heavily on the social networks this time round in the running of his campaign and constantly referred to Johnson's record as being part and parcel of central government's action. Indeed, his opponent lacked a distinct flagship policy that could attract people's attention away from his political allegiance, and neither the clampdown on knife crime, the banning of alcohol consumption on public transport or the promise to abandon the bendy buses in favour of modern Routemasters, or even the Boris Bike scheme would make people forget the formidable success of Livingstone's Congestion Charge or Oyster Card.

At the same time, Prime Minister David Cameron was only too pleased to support Johnson's quest to remain mayor of London given their rivalry to lead the Conservative Party. Once again, the Conservatives had recourse to Lynton Crosby's expertise and the outer boroughs were heavily canvassed in order to harness the traditional conservative vote which had the added advantage of sidelining the "Ken versus Boris" duel. The enthusiastic optimism whipped up by the Olympic Games was also exploited by Johnson's campaign team and for once, the mayor's collaboration with central government seemed to pay dividends. The result was a second victory for Johnson although Livingstone managed to narrow the gap considerably especially with the second preference count which left him only 62,500votes behind, less than half as many as in 2008.

2012 London mayor results

\begin{tabular}{|l|l|l|l|l|}
\hline Candidates & Political parties & First round result & Second round result & Total \\
\hline Boris Johnson & Conservative & $971,931(44 \%)$ & 82,880 & $\mathbf{1 , 0 5 4 , 8 1 1}$ \\
\hline Ken Livingstone & Labour & $889,918(40.3 \%)$ & 102,355 & $\mathbf{9 9 2 , 2 7 3}$ \\
\hline Jenny Jones & Green Party & $98,913(4.5 \%)$ & eliminated & \\
\hline Brian Paddick & Lib Dem & $91,774(4.2 \%)$ & eliminated & \\
\hline Siobhan Benita & Independent & $83,914(3.8 \%)$ & eliminated & \\
\hline Lawrence Webb & UKIP & $43,274(2 \%)$ & eliminated & \\
\hline Carlos Cortiglia & BNP & $28,751(1.3 \%)$ & eliminated & \\
\hline
\end{tabular}

Registered electors: 5,419,193 Turnout: 2,456,990 (37.4\%)

See 2000 \& 2004 tables for abbreviations and sources. 
29 Although Livingstone's strategy had not earned him the mayoralty, the loss of two constituency Assembly seats for the Conservative party can undoubtedly be put down to a popular reaction against government austerity. Likewise concerning the loss of one AM seat for the Liberal Democrats given their record of broken promises on entering the coalition government in 2010.

Livingstone's words on hearing of his defeat marked the end of his attempts to regain the mayoralty and when Johnson declared early on during his second term that he would not be seeking a third mandate, London looked to be in for yet another period of uncertainty concerning its future leadership. ${ }^{23}$ As ever, the 2016 mayoral elections were going to be a formidable competition between the frontrunners for the two main parties, who both in size and ambitions for the capital city were going to differ every inch of the way.

\section{Zac versus Sadiq}

31 Despite the duel that did indeed quickly emerge from the two main parties' primaries, speculation was rife concerning the candidate who could hope to win the third place with Peter Whittle for UKIP being the bookmakers' favourites. He was closely followed by Siân Berry for the Green Party and Caroline Pidgeon for the Lib Dems whose job it was to rebuild bridges between her party and an electorate that was keen to punish it for promise-breaking connivance with the Conservatives. ${ }^{24}$ All three of them were also seeking seats on the Greater London Assembly but Pidgeon was openly optimistic in expressing the belief that her party could reconquer the middle ground left open by the absence of any giant figures such as "Ken" or "Boris". She pleaded the cause for a City Hall led drive to build more houses, public transport concessions for low-paid workers and a hike in the congestion charge. Berry proposed flat-rate fares in public transport, the creation of a renters' union and a city fund designed to help small businesses. Her flagship policy proposal was the closure of City Airport to be replaced by a mixed-use neighbourhood and whatever candidates felt about this idea, they knew that the Greens had to be handled with care given the importance of second preference votes: London's Greens have constantly made an impact on mayoral priorities and Berry was determined to carry the banner forward. As could be expected, whittle laid a lot of the blame for London's ills squarely in the lap of Europe while Galloway's main argument was his proximity with Corbyn stating on one occasion "If you're looking for a Corbyn in this election, it's me". ${ }^{25} \mathrm{He}$ also made no secret of his utter contempt for Khan, branding him a boring Blairite.

At the outset, Labour had six potential candidates ${ }^{26}$ with Tessa Jowell - former Minister of Culture - being the favourite and Khan a close second with David Lammy on his heels given his experience as a member of the Greater London Assembly. The others, Christian Wolmar, transport expert, Diane Abbott MP and Gareth Thomas MP, stood little chance of being chosen but with the Labour party's leadership in full swing at the same time, loyalties were volatile. Lammy had neither the Olympic experience of Jowell, nor the inside knowledge that Khan had of New Labour but he was more independent and emphasised his ability to speak out for London and Londoners without the shackles of devotion to party loyalty. Wolmar used his expertise on London's transport system to explain how he envisaged improving the capital city while Abbot offered more traditional socialist ideas. Thomas, on the other hand, came across as being the most original of them 
all with his concept of transforming London into a city state with far greater powers "devolved" to the Greater London Authority.

Jowell quickly produced her catch-phrase "One London" during hustings while Khan offered "Winning for a purpose". Khan had held on to his Tooting seat in the 2015 General Elections and contrary to the national trend, Labour had done well in London winning 45 of the 73 seats thus giving him the impression that he could rely on strong political support within the boundaries of the capital. Until now, Khan had both admitted in private that running for the job of London mayor was a distinct possibility while publicly dodging questions on the issue. He was torn between the possibility of a ministerial position in a Milliband government and the idea of running for the job of mayor. Indeed, in December 2013, his editing a collection of essays entitled Our London for the Fabian Society that he chaired had been hailed as a sure sign that in the case of a Labour defeat in 2015 , he would definitely attempt to become London's fifth directly elected mayor. ${ }^{27}$ It took Milliband's resignation following Labour's humiliating General Election defeat for Khan to throw his hat into the ring without the added burden of a conflict of loyalties and his resignation from the Cabinet was a sure sign that he had the mayoralty firmly in his sights.

Two points all the Labour candidates had in common were their lukewarm commitment to put their mayoral weight - if elected - behind airport extensions, be this at Gatwick or Heathrow, given the potential vote loser that this issue could become. ${ }^{28}$ Secondly, they all knew to what extent the housing question was crucial to any candidate's legitimacy as mayor of London. Both airport extensions and housing were not important as flagship policies given the limited power mayors can wield in these fields but they were crucial in forming an outline for the sort of governance candidates felt was best adapted to London. Crucial also in their ability to allow candidates to reach out across party boundaries in order to harness second preference votes given the single transferable vote system used to elect mayors. ${ }^{29}$

But at this point, the leadership competition for the Labour party ricocheted onto the party's primary to designate their candidate for the mayoral election: having entered the competition at the last moment, Jeremy Corbyn and his left-wing stance were experiencing a surge in popularity not so much within the party as among party members. Khan had supported Jeremy Corbyn's candidacy but had also somewhat paradoxically stated that he would have little interest in being part of his shadow cabinet, defending his choice by arguing that pluralism was a necessary ingredient of any leadership election. ${ }^{30}$ Abbott, Wolmar and Lammy stood to benefit from a Corbyn victory given their political leanings whereas Jowell would undoubtedly lose out. Meanwhile, the faith issue was simmering away popping up here and there to remind candidates and Londoners that asking Muslims to vote for a fellow worshipper would be a mistake just as much as scaring electors into shying away from him because of his religion. This said, a Yougov poll conducted in August 2015 showed that $31 \%$ of Londoners felt "uncomfortable" about the idea of having a Muslim mayor. ${ }^{31}$

The result of the vote undertaken by the affiliated members of the Labour Party, the $£ 3$ "registered supporters" 32 and full-time party members was proclaimed on $11^{\text {th }}$ September, 2015. To general surprise, Sadiq Khan won against Tessa Jowell with $58,9 \%$ of votes after four rounds. ${ }^{33}$ The next day, Jeremy Corbyn was elected leader of the Labour Party with a landslide victory that saw him win 48,152 votes (59.5\%) on his ostensibly leftwing anti-austerity platform. The lurch to the left of the Labour Party was unmistakeable 
and the party's candidate for the London mayoralty would have to dovetail his own brand of politics for the capital into the new political reality of his party.

The Conservatives had preselected four candidates, Andrew Boff, a GLA assembly member, Syed Kamall MEP, Stephen Greenhalgh who had headed Boris Johnson's Office for Policing and Crime and Frank Zacharias Robin - Zac for short - Goldsmith. The latter campaigned as the natural heir to Boris Johnson - including the Garden Bridge - and made little secret of his aim to solve the housing crisis by building on and redeveloping brownfield sites that according to him were readily available within the boundaries of the capital. Goldsmith had inherited his fortune from his father and invested a great deal of it in the Ecologist, a monthly magazine devoted to issues about international ecology. He had come into politics after the 2005 General Elections when the Conservatives were endeavouring to revamp the party and integrate a plethora of young politicians into their ranks: people like Goldsmith were precious in that they gave the party the greener tinge that it felt it was lacking. ${ }^{34}$ In the 2015 General Elections, Goldsmith had increased the majority obtained in 2010 in his Richmond constituency quite substantially. He thus legitimately believed that Conservative support for him could be repeated across the capital if the Crosby war machine drummed up the traditional support that it had achieved in the previous two elections. ${ }^{35}$

Throughout the whole selection process, victory for Goldsmith seemed a foregone conclusion which explains the lack of ceremony when on 2 October, the results were announced: Goldsmith received a blistering $6,514(70,6 \%)$ of the 9,227 votes cast by party members and any other Londoners willing to pay $£ 1$ in order to vote. His victory was indeed crystal clear but the Conservatives knew that their support in the capital paled into insignificance compared to the involvement of Labour supporters in the primaries for their party. This spoke volumes about the duel between "Zac" and "Sadiq" that was about to unravel.

\section{Mud slinging and dog whistling}

Khan and Goldsmith kicked off their respective campaigns by the popularly perceived housing "crisis" in London. ${ }^{36}$ The former stated not only that May 2016 would be a referendum on the question but that he would use his mayoral power to promote social housing. However, at the same time, he was careful to lay emphasis on its potential to encourage people to move out into the private market as owners. Goldsmith, on the other hand, reasserted his opinion that real estate management in the capital was part and parcel of local community empowerment and that the mayor's involvement should be to "oversee" in order to ensure landscape coherence in London-wide building development. To the average Londoner, more interested in house prices and rents, Goldsmith was seen as avoiding one of the responsibilities that would be laid firmly in his lap should he be elected the following year. Khan, on the other hand, was repeating his life story, telling people about the opportunities and values that had enabled him to climb the ladder, convincing Londoners that he was one of them: he was the son of a bus driver and had not inherited any great fortune from his father. ${ }^{37}$

Europe, too, was another issue where differences were laid bare: Goldsmith was a Eurosceptic whereas Khan believed not so much in any European ideal, as the opportunities it offered the capital to improve its economy. At the same time, the European question enabled him to distance himself from Corbyn's overall anti-capitalist 
stance, reinforcing his voice for London rather than that of any party apparatchik. This logic was taken even further following the terror attacks in Paris on November $13^{\text {th }}$ : Khan's take on Islamist violence harked back to his 2008 Fairness not Favours pamphlet in which he argued that New Labour and the Muslim community needed to rethink their mutual relationship in the wake of Britain's disastrous contribution to the war against Irak. ${ }^{3839}$ Eight years later he emphasised the rights and duties that the different communities owed one another but overall stated how his responsibility as mayor of London would be to protect Londoners, come what may. This stance was repeated on several occasions when Khan boldly stated: "I will be the British Muslim who takes the fight to the extremists".$^{40}$ His mettle was put to the test on December $2^{\text {nd }}$ when in a very emotional debate during which Hilary Benn - Shadow Foreign Secretary - supported Prime Minister Cameron's decision to bomb IS strongholds in Syria, Khan opposed the motion along with Corbyn. ${ }^{41}$

41 From this point, Goldsmith's campaign took a new direction based on the "cultivation of voter anxiety" that was one of Lynton Crosby's fortes. ${ }^{42}$ The strategy behind this negative campaigning was geared to shedding as much light as possible on Khan's relationship with Corbyn while subtly suggesting the links that he might have with some of the more dubious elements of London's multi-faith and multi-cultural population. ${ }^{43}$ Khan's campaign team replied by underlining the amateurism of Goldsmith, his inherited fortune and the fact that he had never had a "proper" job with "real" responsibilities. At the same time, Khan promoted his four year price freeze in London transport to show that his campaign was also about real everyday issues for Londoners but was countered by Goldsmith's announcement that they would be able to buy houses from Housing Associations much in the same way as from Local Councils: this was part and parcel of his "Londoners first" scheme. ${ }^{44}$ These blow for blow tactics did not seem to stop Khan from edging ahead and in an attempt to stem this drift, Goldsmith's campaign team resorted to over-emphasising the link between the Labour candidate and the leftwards moving Labour party under Corbyn's leadership. ${ }^{45}$ Khan replied by multiplying contacts with London's business communities to reassure people that he did not share the Labour leader's anti-capitalism stance and to deflect attacks concentrated on his promised policy of freezing transport charges.

It was at this stage, with two months until the election, that the Sadiqwatch.com website came into full force supposedly to denounce Khan's inconsistencies but in reality, to subtly emphasise the links he supposedly had - or had had - with Islamic extremism. Stories from his past were unearthed when as a lawyer he had argued controversial cases including eleven Kurdish refugees in a conflict with the Metropolitan Police Authority or defended Louis Farrakhan, leader of the Nation of Islam, or Chief Inspector Leroy Logan and Superintendent Ali Dizaei. Khan had also chaired the civil liberties pressure group "Liberty" and following the 7/7 bomb attacks had spoken out in Parliament against Prime Minister Blair's plans to hold terrorist suspects for 90 days without trial. On August $12^{\text {th }}$ 2006, Khan had been one of four Muslim MPs who in an open letter to the Guardian had publicly warned the government about the effects of its foreign policy on terrorist activity in the world stating that it was "ammunition to extremists who threaten us all". ${ }^{46}$ But try as they might, Goldsmith's "dog-whistling" 47 campaign team could not quite manage to strike Lynton Crosby's ${ }^{48}$ chord of fear or stir up sufficient suburban unease because voters were just more interested in the candidates' abilities to communicate about their plans for policing, pollution and housing rather than in negative 
campaigning. ${ }^{49}$ Khan had understood this only too well, knowing that he had far more to lose in a mud-slinging competition than by pressing ahead with his ability to persuade people that the mayor's "soft power", his potential to "enable" rather than to do was safer in his hands than in those of Goldsmith, if only because the latter's sense of municipal responsibility was well and truly steeped in his inherited wealth.

\section{Yes we Khan}

Khan's approach to the mayor's soft power was translated into his Manifesto for all Londoners which contained no flagship policies that his predecessors had been able to promise namely, the Congestion Charge, the Oyster Card, the Olympic Games, Boris Bikes or the Garden Bridge. Khan talked about ambitions and priorities which would be embedded in policies whereas in his manifesto, Goldsmith couched his plans in far more philosophical terms.${ }^{50}$ In no other way could this be better shown than the two opponents respective stances on the referendum about Europe. While Sadiq Khan had made it quite clear that he was campaigning to keep Britain within Europe along with the majority of Londoners and especially the City, Goldsmith's Eurosceptic vision could never have been plainer: for Goldsmith Euroscepticism was an opinion whereas for Khan, remaining in Europe was a policy. ${ }^{51}$ In the same vein, even when Goldsmith attempted to rouse people's fears about Khan's supposed plans to build on the green belt in order to tackle London's housing problem, he fell on relatively deaf ears. These issues were indeed sensitive ones but the negative campaigning used was proving to be unsuccessful. By April, the die seemed to have been cast as opinion polls consistently gave Khan a ten-point lead over his opponent. Then came the black taxi quiz whereby both candidates were grilled by a journalist taking them for a trip across London: after the more political questions, they were asked about the names of local football clubs, tube stops in the centre of town and people and places in popular television series, the things that showed true London grit. ${ }^{52}$ Khan came out on top with Goldsmith showing his lack of knowledge about ordinary everyday life and it began to dawn on the Conservatives that the hidden suburban vote which might just turn the tide was not going to happen. ${ }^{53}$

During the last three weeks before election day, Khan's alleged connivance with extremists was once again underlined by his opponents. Mayor Johnson ${ }^{54}$ and Prime Minister Cameron ${ }^{55}$ temporarily put their differences over Brexit to one side and lined up in a last-ditch attempt to bolster Goldsmith's flagging campaign. They did not so much denounce Khan's extremism as highlight the fact that he had undoubtedly committed errors of judgment which could be repeated if he were given the helm of the capital. They hoped to persuade the swing voters that they had more reasons not to vote for Khan than Goldsmith but their belligerent attitude was condemned even from within their own Conservative ranks. ${ }^{56}$ Yet the worst broadside that Khan would have to face was to come from his own side, from the first mayor of London whose support had been so valuable at the outset.

Ken Livingstone had had brushes on various occasions with the Jewish community in London during his two mandates as mayor and on one occasion had been suspended narrowly escaping losing his mayoral position altogether. ${ }^{57}$ On 27 April 2016, Livingstone appeared on the Vanessa Feltz television show and failed to condemn MP Naz Shah for her anti-Semitic Facebook posts for which she had been suspended from the Labour party. ${ }^{58}$ But not only did Livingstone deal lightly with Shah's outbursts but added insult to 
injury by providing a very questionable analysis of Adolf Hitler's Zionism by saying: "Let's remember when Hitler won his election in 1932, his policy then was that Jews should be moved to Israel. He was supporting Zionism - this before he went mad and ended up killing six million Jews." ${ }^{59}$ The public outcry was considerable and Livingstone branded a "Nazi apologist" particularly during a clash with MP John Mann. ${ }^{60}$ Calls for his suspension from the Labour Party increased in volume and his "friend", Jeremy Corbyn, was criticized for dilly-dallying before taking the decision to suspend him. Khan's campaign team moved quickly in order to reduce the collateral damage that Livingstone's analysis would inevitably cause. Khan duly condemned his mentor stating publicly that these comments were appalling and that his party would have no truck with them using his oft repeated message that as mayor, he would take the fight to the extremists. But his opponents moved quickly too, underlining once again the Labour MPs' inconsistencies that the electorate should be aware of: one of his most valuable supporters was antiSemite whom the leader of his party had failed to condemn swiftly and efficiently and Khan himself had a reputation of tolerating extremists.

On 5 May 2016, 45\% of London's electorate took part in the mayoral elections, considerably more than in 2012 and on a par with the 2008 election when the Boris versus Ken competition had galvanized voters. Khan's victory was a reflection of the failure of Goldsmith's negative campaign which had ended up by revolving almost exclusively around the questions of his opponents' trustworthiness. As was to be expected, UKIP won two Additional Members' seats given the surge in overall support that they had mustered up in the buildup to the referendum. Yet if the composition of the Assembly can be used at all in order to gauge mayoral candidates' support throughout the capital city, the Merton and Wandsworth constituency which contains Khan's Tooting seat, changed hands from the Conservatives to Labour. This was no small triumph given the negative campaigning that Khan had had to put up with and would cause the Conservatives to ponder at length about the mayoral campaign they had endorsed.

2016 London mayor results

\begin{tabular}{|l|l|l|l|l|}
\hline Candidates & Political parties & First round result & Second round result & Total \\
\hline Sadiq Khan & Labour & $1,148,716(44.2 \%)$ & 161,427 & $\mathbf{1 , 3 1 0 , 1 4 3}$ \\
\hline Zac Goldsmith & Conservative & $909,755(35 \%)$ & 84,859 & $\mathbf{9 9 4 , 6 1 4}$ \\
\hline Siân Berry & Green Party & $150,673(5.8 \%)$ & eliminated & \\
\hline Caroline Pidgeon & Lib Dem & $120,005(4.6 \%)$ & eliminated & \\
\hline Peter Whittle & UKIP & $94,373(3.6 \%)$ & eliminated & \\
\hline Sophie Walker & Women's Equality & $53,055(2 \%)$ & eliminated & \\
\hline Georges Galloway & Respect & $37,007(1.4 \%)$ & eliminated & \\
\hline Paul Golding & Britain First & $31,372(1.2 \%)$ & eliminated & \\
\hline Lee Harris & CISTA & $20,537(0.8 \%)$ & eliminated & \\
\hline
\end{tabular}




\begin{tabular}{|l|l|l|l|l|}
\hline David Furness & BNP & $13,325(0.5 \%)$ & eliminated & \\
\hline Prince Zylinski & Independent & $13,202(0.5 \%)$ & eliminated & \\
\hline Akit Love & One Love & $4,941(0.2 \%)$ & eliminated & \\
\hline
\end{tabular}
of one of the 7/7 buses destroyed by terrorists. The title of the article ran: "Are we really going to hand the world's greatest city to a Labour Party that thinks terrorists are its friends?" It sparked off an outcry the most telling of which was "This is not the Zac Goldsmith that I know". ${ }^{61}$ By listening too intently to the sirens of Crosby's team, Goldsmith had unhappily campaigned himself into a corner. ${ }^{62}$ When challenged directly, when he spoke as the Goldsmith people had known before the mayoral campaign, he refused to say that Khan was anti-business, anti-Semite or that he had ever connived with any extremist movements. Yet rather than bow out honorably, until the last minute he was adamant that his campaign had been evenhanded given that in his opinion London deserved a mayor who would not compromise with the truth. He had clutched at straws, hoping that the feeling of unease he could conjure up might just give him the edge over Khan. But the suburban resistance to change which his campaign had tried to foster had failed to convince faced with the progressive pro-growth attitude of his opponent. governance that the electorate was interested in: policing pollution, the environment, transport, housing, tax and business. For each different audience he addressed throughout his campaign, he made sure that his capitalist endeavor corresponded to the soft power that he would wield as mayor of London. At no other time was this more obvious than during his acceptance speech at City Hall minutes after the results were proclaimed. In the style that people had become accustomed to, Khan once again repeated his message about the opportunities London could give and the ambitions he had for the city stating that he was proud that London had chosen "hope over fear and unity over division". ${ }^{63}$ Two days later when Khan was officially signed in to be the next mayor of London he stepped forward and said "My name is Sadiq Khan and I'm the Mayor of London" ${ }^{64}$ The self-declared British Muslim had made it clear that despite the difficult campaign during which mud-slinging had too often replaced honest debate about policies for London, the electorate had still been able to elect the candidate who had not missed the bus: Khan had shown that he could.

51 Timothy WHITTON est Professeur de civilisation britannique à l'université de Clermont-Auvergne (UCA). Chercheur à l'EHIC (EA1087), ses travaux s'intéressent principalement à la civilisation britannique contemporaine et plus particulièrement à la décentralisation du pouvoir et à la pratique référendaire au Royaume-Uni. 


\section{BIBLIOGRAPHY}

HILL, Dave, Zac versus Sadiq : the Fight to Become London Mayor, London: Double Q Books, 2016, p.98.

TROUVE, Susan (dir.), Les Coulisses du pouvoir, Observatoire de la Société Britannique, $\mathrm{n}^{\circ} 6$, juin 2008.

WHITEHOUSE, Wes, GLC - the Inside Story, Middlesex: James Lester Publishers, 2000.

Revue Française de Civilisation Britannique vol. VX, n²4, eté 2010 \& Hors série n², été 2009.

WHITTON, Timothy, Ken « le rouge » et la Mairie de Londres. Du Greater London Council à la Greater London Authority, Paris: l'Harmattan, 2010, 212p.

- "All "Kens" to all men. Ken the chameleon : reinvention and representation. From the GLC to the GLA”, in 'Présentations, re-présentations, représentations', Revue Française de Civilisation Britannique, vol. XV, n4, été 2010, pp. 131-147.

- "Over to you Boris : the defeat of Ken Livingstone in 2008", in Londres : capitale internationale, multiculturelle et olympique, l'Observatoire de la Societé Britannique, Université du Sud ToulonVar, $n^{\circ} 11$, décembre 2011, pp. 123-145.

- "Ken Livingstone: the Thorn in (New) Labour's Side", in, LISA E-journal, XII-n8, The UK's Political Landscape in the 21st Century: Players, Strategies, Achievements, 2014.

\section{NOTES}

1. The battle between Livingstone and Thatcher that led to the abolition of the Greater London Council - headed by the former - in April 1986 is detailed in my articles "All Kens to all men. Ken the chameleon : reinvention and representation. From the GLC to the GLA", in, "Présentations, représentations, représentations', Revue Française de Civilisation Britannique, vol. XV, nº été 2010, p. 131-147 \& "Ken Livingstone : the Thorn in (New) Labour's Side”, in, LISA E-journal, XII-n8, The UK's Political Landscape in the 21st Century: Players, Strategies, Achievements, Panorama du paysage politique britannique au XXIe siècle : acteurs, stratégies, réalisations, 2014. Detains of what Livingstone and his team got up to during the period prior to abolition in 1986 are recounted in Wes WHITEHOUSE, GLC - the Inside Story, Middlesex: James Lester Publishers, 2000.

2. This was Khan's rallying call during his campaign and a reference he still fondly uses. See for example the State of London debate, 30 June 2016.

3. This aspect is discussed in my article: "La pratique référendaire et la Mairie de Londres ", in, 'La pratique référendaire dans les îles britanniques', Revue Française de Civilisation Britannique, Hors série n² 2 été 2009 , p. 67-84.

4. The parliamentary debate on 6 June 1997 (col. 736-738) gives an interesting - albeit sarcastic insight into New Labour's tendency to constantly associate the "people" with politics.

5. « La pratique référendaire et la Mairie de Londres », op. cit.

6. Events explaining these primaries leading to Livingstone running as in independent candidate and his exclusion from New Labour are detailed in my article " 'Nightmayor at City Hall', les coulisses d'une investiture, d'une élection et d'une réélection à Londres”, in, Susan TROUVE, directrice de publication, Les Coulisses du pouvoir, Observatoire de la Société Britannique, $\mathrm{n}^{\circ} 6$, juin 2008, p. 197-225. 
7. Kramer tried to stand out from the crowd by wearing orange Doc Martens while campaigning.

8. If no candidate receives $50 \%$ of the votes, the second preference votes of the eliminated candidates are added to the two winning candidates' totals.

9. Candidates who fail to receive $5 \%$ of first preference votes lose their deposit.

10. For this purpose, London is divided into fourteen electoral constituencies.

11. On 10 September 2003, the Guardian had declared that "Livingstone [was] the most influential person on public services in Great Britain."

12. The Mayor of London is directly accountable to Londoners on two occasions every year during People's Question Time and once a year during the State of London debate.

13. Including the Conservative Party.

14. One of Livingstone's best speeches can be viewed at: http://www.youtube.com/watch? v=6BSIBPsbL9c date accessed 1 December 2016. The attacks came just hours after London had been awarded the 2012 Olympic Games by the Olympic Committee in Singapour.

15. The Sheikh Yusuf al-Qaradawi, the Olivier Finegold and the Jean-Charles Menzes affair, the Alison Lapper Pregnant statue in Trafalgar Square, the Reuben brothers affair, the extension of the Congestion Charge, criticism of Human Rights in China, the "Brooms for Oil" deal with Hugo Chavez and the Lee Jasper affair to name but a few. For full details see my article "Over to you Boris : the defeat of Ken Livingstone in 2008", in, Londres : capitale internationale, multiculturelle et olympique, l'Observatoire de la Societé Britannique, Université du Sud Toulon-Var, n¹1, décembre 2011, p. 123-145.

16. "Boris Bikes", which are an imitation of the Parisian "Vélibs", had been initiated by Livingstone.

17. Ibidem, p.139.

18. This was called the "doughnut" policy whereby the Conservatives concentrated their efforts on the outer ring far more than Inner London where Livingstone was popular and they knew that votes would be harder to get.

19. Statement made at the launch of his campaign to be chosen by the Labour Party ( 01 June 2010), "I want to be Mayor for one overriding reason: if I am elected, my focus will be to do everything I can to protect Londoners from the recession and the effects of the Government's policies" \& The Government's cuts are his cuts, in "Boris sets his sights on race to be Olympics mayor", The Times, 11 September 2010.

20. On learning on 24 September 2010 that he had been chosen as the Labour Party's candidate, Livingstone declared amongst other things "If you want to get them out, you start by getting out Boris Johnson".

21. See note 1.

22. "Britain - Livingstone makes bid for 2012 Mayoral Election”, Morning Star, 20 March 2009.

23. Johnson's decision also fueled speculation concerning his possible bid to wrest the leadership of the Conservative party away from Cameron.

24. In the 2015 elections, the Lib-Dems had won only one seat out of the 73 in London.

25. "George Galloway: if I was Jeremy Corbyn I'd want me to be London mayor", The Guardian, 25 November 2015.

26. Candidates had to secure the nomination of at least five of the 73 London Labour Constituency Parties in order to run.

27. Sadiq KHAN (ed.), Our London: the capital Beyond 2015, Fabian Society, Fabian Ideas 634, December 2013.

28. In October 2016 Goldsmith resigned as an MP to express his disagreement with the decision to build a third runway at Heathrow. He ran for re-election as an independent candidate but was soundly beaten by Liberal Democrat candidate, Sarah Olney.

29. Voters can express second preferences on their ballots. If no candidate receives $50 \%$ of votes, the ballot papers for the two candidates who received the most first preference votes are put to 
one side. All the other candidates are eliminated and their second preference votes added to the two candidates who received the most first preference votes.

30. In the actual leadership contest, Khan had voted for Andy Burnham, a far more moderate candidate than Corbyn.

31. "One in three Londoners feel 'uncomfortable' with the prospect of a Muslim Mayor poll finds; two leading Conservative and Labour candidates for London Mayor are Muslims", The Independent , 13 August 2015.

32. Electors willing to pay $£ 3$ and sign the Labour Party's charter to take part in the selection of the Party's candidate.

33. The single transferable vote system was used here too.

34. It was their reputation of being the "nasty party" that they were trying to shed.

35. The increase in support was undoubtedly due to the swing away from the Liberal Democrats, given the conditions on which they had accepted to enter the coalition in 2010.

36. “Zac Goldsmith proposes amendments to housing bill because of London; Tory mayoral candidate tells Commons proposed legislation should require councils to build two affordable homes for every one sold off", The Guardian, 02 November 2015.

37. "You make sure you can defend yourself'; in the first major interview of his campaign, Labour's surprise candidate for mayor of London, one of eight children from a boxing-mad working-class family, talks about his incredible journey", The Observer, 8 November 2015.

38. 'Sadiq Khan: Labour's mayoral candidate for London says Muslims must root out 'cancer' of radicalisation;

Mr Khan warned that growing radicalisation was a 'cancer eating at the heart of our society all the time', The Independent, 19 November 2015.

39. "Sadiq Khan's words on Islamists and Britain were authentic and shrewd; the Labour mayoral candidate's speech about the Paris attacks, his family and his fellow Muslims combined political know-how and true conviction", The Guardian, 20 November 2015.

40. See for example Khan's speech at One Great George Street conference centre, 20 March 2016.

41. Benn's full speech can be viewed at: https://www.theguardian.com/politics/video/2015/ dec/03/hilary-benn-airstrikes-vote-speech-full-must-confront-isis-evil-video date accessed 1 December 2016.

42. Dave HILL, Zac versus Sadiq : the Fight to Become London Mayor, London : Double Q Books, 2016, p.98.

43. "London mayor race: could Jeremy Corbyn be Zac Goldsmith's best friend?; the Labour leader's standing with the capital's voters will be a problem for his party's City Hall candidate if the latter's Tory rival has his way", The Guardian, 1 November 2015.

44. “As mayor, I will have a 'Londoners First' rule; I've worked hard to get a better affordable housing deal for the capital - unlike Labour's Sadiq Khan”, The Daily Telegraph, 20 January 2015.

45. "London mayor race: can Zac Goldsmith catch Sadiq Khan; the Labour candidate looks on course to win back City Hall for his party but a lot could have changed by 5 May", The Guardian, 10 January 2016.

46. "Muslim leaders say foreign policy makes UK target", The Guardian, 12 August 2006.

47. "Zac Goldsmith's dog-whistle is becoming a racist scream”, The Times, 12 April 2016.

48. During one husting, Khan declared how Crosby's tactics had changed Goldsmith's campaign into a "negative, divisive" one. Dave HILL, op. cit., p.217.

49. The "wealth tax" or "jewellery tax" as it was popularly dubbed, aimed specifically at some ethnic minorities for whom jewellery is an important family asset, was a case in point given that mayors do not have the power to raise such a tax should they even want to. Designed to scare, this threat held little water under closer scrutiny.

50. My Action Plan for Greater London.

51. Dave HILL, op cit., p.180.

Revue Française de Civilisation Britannique, XXII-4 | 2017 
52. Goldsmith: https://www.youtube.com/watch?v=KFG8Sg9y1i0 \& Khan: https:// www.youtube.com/watch?v=tTGgDxK5SoE date accessed 1 December 2016.

53. Goldsmith made an even bigger gaffe showing his lack of "football" knowledge when at the beginning of May he declared that like Leicester City, he hoped to come from behind to win the mayoral elections at the last moment. By this time, Leicester, which won against all odds, had been at the top of the league for 14 weeks.

54. "I'm off - but don't let Labour bring Ken's chaos back to City Hall; The next Tory mayor, Zac Goldsmith, is superb - and, let's face it, much better-looking than me”, The Daily Telegraph, 2 May 2016.

55. Hansard, cols. 913 \& 916, 20 April 2016.

56. "Zac Goldsmith accuses Sadiq Khan of 'giving cover to extremists'; Tory candidate for London mayor accuses his rival of helping 'those who seek to harm our police and capital', The Guardian, 20 April 2016 \& “Top Conservatives condemn Zac Goldsmith's 'disgusting' mayoral campaign; David Cameron under pressure to justify attempts to link new London mayor Sadiq Khan to alleged Islamic extremists", The Guardian, 7 May 2016 \& "Sadiq Khan says Tory smear campaign was 'straight out of the Donald Trump playbook'; Goldsmith's campaign could increase 'risk of terrorism and radicalisation', says prominent Muslim Tory", The Independent, 8 May 2016 \& "I worked for Zac Goldsmith's failed campaign - and this is what it looked like from the inside; I expressed my concern about racial profiling. Instead of being frustrated by the negative press coverage, senior campaigners told me the controversy was a good thing", The Independent, 10 May 2016.

57. Details of these brushes can be found in my book Ken 'le Rouge' et la Mairie de Londres. Du Greater London Council à la Greater London Authority, Paris: Harmattan, 2010, p. 142, 145, 152, 155, $190,191 \& 192$.

58. In one of the most publicised posts, Shah called for Israel to be "relocated" in the US.

59. Livingstone completed his vision of Hitler's Zionism by the following statement: "The simple fact in all of this is that Naz made these comments at a time when there was another brutal Israeli attack on the Palestinians; and there's one stark fact that virtually no one in the British media ever reports, in almost all these conflicts the death toll is usually between 60 and 100 Palestinians killed for every Israeli. Now, any other country doing that would be accused of war crimes but it's like we have a double standard about the policies of the Israeli government."

60. This clash can be seen here: https://www.youtube.com/watch?v=tJCzVV5eIg8 date accessed, 1 December 2016.

61. Tweet from Baroness Warsi former co-chair of the Conservative Party, reported in "Zac Goldsmith criticised by former Tory Minister Baroness Warsi over Sadiq Khan 7/7 London terror bus image; ‘This is not the Zac Goldsmith I know”, The Independent, 1 May 2016.

62. Lynton Crosby received his knighthood on the same day that Sadiq Khan was elected Mayor of London.

63. Khan's speech can be seen at https://www.youtube.com/watch?v=uuz10fZgZ_o date accessed 10 December 2016. Paul Golding, leader of the Britain First Party, can be seen turning his back on Khan during the mayor elect's speech.

64. Notably, Jeremy Corbyn was not present at this ceremony. 


\section{ABSTRACTS}

In May 2016, the Labour Party's candidate, Sadiq Khan, became the third mayor of London after a bitter competition against Zac Goldsmith, his opponent from the Conservative Party. During his campaign, Khan promised a more consensual approach to politics in the capital city thus distinguishing himself from his predecessors, Ken Livingstone, mayor from 2000 until 2008 and Boris Johnson who held the post from 2008 until 2016. This article briefly looks back at the first mandates of "Ken" and then "Boris" to provide elements of comparison with the 2016 London elections. Four times in a row the competition was reduced to a duel between the candidates from the two main parties. The 2016 election which opposed "Sadiq" and "Zac" stands out as having rapidly become a real fist-fight that undoubtedly Londoners will be only too happy to consign to the dustbin of the capital's municipal history.

Au mois de mai 2016, Sadiq Khan, candidat du Parti travailliste, devient le troisième maire de Londres après une rivalité particulièrement acharnée avec Zac Goldsmith, son adversaire du Parti conservateur. Lors de sa campagne, Khan promet une approche plus consensuelle de la politique dans la capitale et marque ainsi sa différence par rapport à ses prédécesseurs à ce poste, Ken Livingstone, maire de 2000 à 2008, et Boris Johnson qui occupe le poste de 2008 à 2016. Cet article retrace brièvement les premiers mandats et campagnes de «Ken " puis de «Boris " et fournit des éléments de comparaison avec les élections de 2016 dans la capitale. Par quatre fois, la compétition s'était réduite à un duel entre les candidats des deux grandes formations politiques. Celle de 2016 qui oppose «Sadiq " à « Zac» se distingue en ce qu'elle se transforme rapidement en pugilat que les Londoniens souhaiteront sans aucun doute rapidement consigner aux oubliettes de la politique municipale de leur ville.

\section{INDEX}

Mots-clés: Maire de Londres, campagne électorale, taxe anti-embouteillage

Keywords: London mayoral election, Greater London Authority, Congestion Charge

\section{AUTHOR}

\section{TIMOTHY WHITTON}

Université Clermont-Auvergne (UCA) EA1087 EHIC, 63000 Clermont-Ferrand 